\title{
COMPARATIVE ANALYSIS OF SEXUAL SOCIALIZATION OF PUPILS IN THE EU COUNTRIES AND UKRAINE
}

\section{Kravets V. P., Kravets S. V.}

\section{INTRODUCTION}

The European Union has entered the era of unified social standards, and sexual socialization at the beginning of the 21-st century is in all the countries. Moreover, it has to be in all the countries that have signed "European Social Charter". All this sharply contrasts with the actual running in place of educational projects of domestic officials and deputies. In Ukraine sexual socialization until today has had a declarative character, when from the official stands are heard the words about the need for such education, in reality the problem is delegated to the amateurs and enthusiasts (without economic and financial subsides, without organizational and financial aid, etc.). Political reforms, economic cataclysms, destruction of old social structures and the birth of the new ones transform human psyche, causing a variety of ideological and psychological mutations. This cannot but affect the family and sexual life of society, in which, with all the diversity of styles and scenarios of relations between the sexes on different age, property and educational "levels" there are some common trends, especially tangible in youth environment with its own subculture.

Comparative historical analysis of sexual behavior, attitudes and values of different countries in the last half century shows a sharp decrease in the behavioral and motivational differences between men and women in the age of sexual debut, the number of sexual partners, display of sexual initiatives, attitudes towards eroticism, etc. However, the tendency to align gender differences in the sphere of sexual values and behavior in Ukraine is much weaker than in the West.

In connection with the foregoing, it is the study of the foreign experience of the sexual socialization of schoolchildren, since the processes, which we have faced recently, have a global nature. But in western countries they were manifested much earlier and therefore they are better explored and it allows to speak not only about the reasons of the relevant phenomena, but also about possible long-term consequences. It is worth noting that for those who hate all American, it does not make sense to take as a role model everything that is overseas. Many conclusions of Ukrainian teachers are based on the results of European studies, as traditional domestic culture and mentality by 
a number of parameters are historically closer to European ones than to American examples.

\section{The history of sexual socialization in Western Europe}

Assessing the history of sexual socialization in Western Europe, it is possible to point out in it several large periods. For the first period (the end of the 19-th century to the mid 1920-s) is characterized by disputes about the goals and content of sexual education, the first experiments of its implementation. Organizers of women's movements in Europe A. Bebel, K. Tsetkin, M. Godan, v. Rayh and others demanded uniform sexual and reproductive rights for men and women. The doctrine of Freud changed attitudes in society to sexuality. It is now increasingly discussed on the special press pages.

Two opposing methodological approaches were highlighted in this regard. Within one of them were offered to consider sexuality as self-worth, beyond its connection with marriage and childbearing, whereas within the second one, sexuality and its manifestations were considered exclusively in connection with the purpose of establishing a family and procreation ${ }^{1}$. In European countries, there were numerous discussions on the feasibility of special training of schoolchildren for adult independent life.

The second period (the end of 1920's-1940's years) is characterized by the fact that sexual socialization becomes a matter of public organizations which used the need of young people in information on reproductive and sexual health issues for their political purposes. M. Hirschfeld created a "Worldwide League of Sexual Reforms" that united in its ranks the researchers of sexual problems and supporters of sexual reforms around the world. The work of the League, in addition to systematic sexual education, was aimed at preventing prostitution and sexually transmitted diseases, protecting the political, economic and sexual rights of women.

In the 1930's great influence on the ethical and moral values of the population of the Western European countries had the idea of German National Socialism. Psychoanalysis of Freud got into disfavor of the National Socialist pedagogy. Traditional sexual repressions were restored. Sexuality was again limited by procreation function. Any research and consulting work on sexual education was reduced, the literature on sexual subjects was destroyed.

Recognizing the problem of child and teenage sexuality topical and paying attention to the need to solve it, pedagogy has not had any effective means. As a promotional means of sexual education M. Deens pointed to the

\footnotetext{
${ }^{1}$ Кравець В.П. Сексуальна педагогіка. Навчальний посібник. Тернопіль : ТНПУ ім. Гнатюка, 2016. 320 с.
} 
need to fill the free time of schoolchildren with socially useful activities, which, in his opinion, will allow to reject sexual impulses that appear, and direct them in the sphere of spirit, sport, arts and social service ${ }^{2}$.

The third period of history of sexual socialization (1950's - 1980's) takes its count after the Second World War. Division of the world into two antagonistic camps, the beginning of the arms race, the hard period of the post-war rebuilding, the crisis of marital and family relationships, a significant increase in prostitution and the spread of sexually transmitted diseases in the postwar period - these and other factors which have affected the attitude towards sexual socialization of schoolchildren.

The sexual revolution of the 60-70's of the 20-th century made a significant influence on the formation of positive attitudes to sexual socialization. It has determined the change of sexual morality norms, weakening of social control of premarital behavior of youth, expansion of boundaries of language decency, etc. The old morality that has reduced the sexual relations to the marriage framework was regarded by many liberal Europeans not only as outdated but also improper. Among the positive trends of the sexual revolution can be noted the following: information blockade breakthrough; intensification of scientific researches in the field of sex and sexuality; the width of public discourses; availability of contraceptives and intimate means and the ability of the population to use them; mass sexual education; emancipation of the individual. Under the influence of the sexual revolution, sexual pedagogy declared itself fully in most European countries.

But already in the 1980's due to the AIDS epidemic in the vast majority of world countries gradually changes the attitude to sexual education, and the main informant on this issue was a general education and professional school. At the same time, the countries, which were in antagonistic camps approached to solving the problem of preparing the school youth to family life differently.

In the socialist camp countries, the main emphasis was on the preparation of the future familtman and responsible fatherhood. (USSR, GDR, PNR). Unlike the countries of socialist camps in the West, the emphasis was on sexual socialization, which got actualization in many countries in Western Europe. Convinced of the fruitiness of prohibitions and ineffectiveness of family sexual socialization, most western countries at the end of 20-th century started creating public systems for sexual socialization of children and adolescents. In some countries (GERMANY, Belgium, France) a ban was lifted on sexual education in the walls of secondary schools, and in others (Sweden, Netherlands, Denmark) it was introduced as a compulsory

${ }^{2}$ Дебесс М. Подросток. 20-е изд. Санкт-Петербург : Питер, 2004. 127 с. 
subject. Many teachers and physicians in European countries have acquainted teenagers with problems of sexual relations and procreation. Today, the emphasis is not on prohibitions but on convincing and education. It appeared that sexual and sex education did not accelerate the sexual debut of pupils.

The fourth period of the history of training students to family life begins in the late 20-th century. It is characterized by significant changes on the geographical and political map of the world. United Germany was created, the Soviet Union, Czechoslovakia and Yugoslavia collapsed, as a result of which more than 20 new independent states appeared on the European map, the European Union and NATO transformed. Society enters its next phase of postindustrial development - informational. A computer, a mobile phone, the internet, the social networks, etc appear. Feminist movement, demographic problems, liberalization of sexual morality, decrease in fear of the unwanted pregnancy and venereal diseases contributed to the intensification of sexual activity of women, emancipation of female sexuality.

Today in Europe there is a clear shift of the values of the people which undoubtedly affect the sexual socialization of schoolchildren: the legalization of same-sex love; rehabilitation and normalization of unproductive sexuality (masturbation, oral sex, other sexual techniques that do not lead to fertilization) ${ }^{3}$; sex depersonalization of a child, appearance of the third - uncertain $\operatorname{sex}^{4}$; the possibility of legalization of incest as "gender norm" (Sweden, Denmark and Switzerland); the increase of number of participants in the child free movement (free of children); propaganda of "postpartum abortion", etc.

On this background, individualization and privatization of sexuality occurs, the transition from external social control to individual selfregulation is carried out. Democratic society refuses strict regulation and unification of sexual life, preferring pluralism and tolerance. Sex ceases to be only a tool of procreation, it now has other tasks - from getting pleasure to the growth of self-esteem.

All of the above led to serious social consequences associated with intersex relationships. Thus, for example, at the end of the 20-th - early 21-st century in the UK high birth rate among girls of 15-19 years (30 out of 1000), the highest in Western Europe. The official teenage pregnancy statistics (data from the National Health Service of 2001) states: "There are

3 Таежная А. Эволюция гендера. Как менялись роли мужчины и женщины в обществе URL: https://www.wonderzine.com/wonderzine/life/life/201607-gender-role-playing

4 Потапова T. Життя без дітей: чайлдфрі по-українськи URL: https://life.pravda.com.ua/travel/2009/11/12/33004/. 
7981 pregnancies recorded in girls under 16 in 2001 year (ratio of 8 to 1000 girls aged $13-15$ years $)^{5}$.

According to the ISSP (International Social Research Program) in Germany, more than 7000 juvenile girls gave birth to a child in $2005-45 \%$ more than in previous years. In addition, the amount of pregnancy termination in adolescents increased: from 2004 to 2005 at one fifth, from 5763 to 6909 . Also to $20 \%$ increased the number of abortions in girls younger than 14 years of age - from 574 to 696. According to the French researcher A. Sohn (Sohn A., 1996), French youth is characterized by a horrible picture of sexual ignorance and associated fears, tragic errors and abuse $^{6}$.

According to the Danish survey of school youth, respondents in the secondary education system lacks basic knowledge of STD, contraception, body and sexuality as a vital part of the personality, in particular, $20 \%$ of pupils believe that they lack information about the functions of body and sexuality, $15 \%$-about contraception, $25 \%$-about pregnancy and abortion. In addition, $30 \%$ of pupils answered that they know little about sexual rights, $29 \%$-about different forms of sex, $27 \%$ of pupils are convinced of the insufficiency of their knowledge about negative sexual activity (sexual abuse and violence, perversion, pedophilia, etc. $)^{7}$.

Not all in practice of sexual socialization of foreign countries must be welcomed and adopted. Especially alarms the desire of some of them to propagate homosexual subjects. In the UK, since 2014 a new curriculum was planned to introduce homosexual topics into all school curriculum subjects. In German social pedagogy, the concept of the third non-traditional gender was introduced, which is called "uncertain", referring to the possibility to choose the gender at will before the person becomes 18 .

Summarizing the modern programs of sexual socialization, which are implemented in many countries at the state level, it is worth noting that they are usually developed in the mainstream of two areas - conservative and liberal. In liberal programs, sexuality is understood as an important life value. The medical and hygienic aspects of sexual behavior, the issue of abstinence from early sexual intercourse, and the preservation of reproductive health are discussed. Female and male reproductive organs,

5 Левчик Н.С. Підготовка учнівської молоді до виконання батьківських обов'язків у США та Великій Британії : дис. ... канд. пед. наук : 13.00.07 / Наталія Стефанівна Левчик, 2010.180 с.

${ }^{6}$ Sohn A.M. Du premier baiser f la cove: La sexualite des Francaisau quotidian (1850-1950). P : Aubier, 1996.866 p.

${ }^{7}$ Haeberle E. Children's sexual thinking. A comparative study of children aged 5 to 15 years in Australia, North America, Britain and Sweden. London : Routledge \& Kegan Paul, 2013. 42 p. 
causes of sexually transmitted diseases, conditions of prevention of pregnancy and sexually transmitted disease are studied, the skills of using contraception and liberal attitudes toward other people's sexual behavior are developed. At the same time, the task of forming a moral relationship between teenagers of different sexes becomes secondary. The only obligatory and cultivated norm is the feeling of responsibility for the nature and consequences of sexual relations.

Conservative programs are devoted to the formation of moral relations between the sexes, maintaining from early sexual contact as only the right way of solving the problem. Acquaintance of children with physical signs and manifestations of gender is considered undesirable. Knowledge of reproductive processes and functions is given very gradually and cautiously: it is recommended to explain taking for the example plants, but not animals, in order to avoid premature perceptions of the biological nature of human reproduction.

However, in some EU countries (for example, in Poland) the programs that Polish scientists called the strategy and tactics of the "golden mean" are used. The best characteristics of the two mentioned have been synthesized in these programs. Sexual socialization should not and cannot begin with providing absolute sexual freedom - it should create clear models of desired attitude and behavior and take care of their full and profound internalization by young people ${ }^{8}$.

None of these models is worse and no better than another. Adoption of these existing in society models is regulated by individual attitude to sexuality and sexual socialization; there is always a distance between the attitudes of a particular model and the real sexual socialization process.

To summarize the positive aspects of the European sexual socialization system, it is possible to point out the following: the adults respect young people and believe that they can act responsibly; the sexual policy is based on scientific data, not the interests of political and religious groups; real measures are used to overcome difficulties and diseases, including wide access to education, contraception, etc.; in most European countries, "sexual education" became a school course; sexual education is not necessarily a separate subject, it can be included into all school subjects and is conducted at all stages of training; the families openly and honestly discuss with the teenagers the problems of sexuality and support teachers and physicians in shaping sexual culture; European countries are trying to take into account cultural diversity in relation to immigrants whose values may differ from the culture of the majority and so on.

\footnotetext{
${ }^{8}$ Каган В.Е. Воспитателю о сексологии.Москва : Педагогика. 1991. 256 с.
} 
Analyzing the guidelines of the European governments and the work of the famous modern teachers we can conclude that sexual socialization is aimed at: promotion of psychosexual development of schoolchildren; promotion of tolerant attitudes towards sexuality; promotion of respect for sexual diversity and gender differences; teaching pupils of responsible sexual behavior; warning early sexual relations; providing conscious perception of risks of early contacts; confronting stereotypes and myths about sex distributed by peers, youth press and Media; informing the youth about access to medical and consulting services; prevention of the use of inappropriate material as visual aids; not using the street terminology in conversations with children; introducing children and teenagers with the basics of personal hygiene; discussing the issue of proper use of female hygiene products; providing mechanisms for protecting schoolchildren from sexual exploitation; caring out preliminary instruction of sexting for students; forming an adequate attitude of the youth to sexual health; contribution to shaping the ability to deny something, etc.

Foreign experience of sexual socialization convinces that the block of work related to sexual education should contain inextricably linked didactic (informational and educational instrumental) and educational (personaloriented) components, which ensure the formation of students' adequate ethical norms, value orientations, knowledge and skills, adopted on a personal level, realized in behavior, especially because sex education is inextricably associated with morality. At the same time, the process should be preemptive and prophylactic, not sexually-stimulating, and focus on the norm, rather than rejection as a means of intimidation, and contain an analysis of various aspects of their own sexuality (functional, sensoryemotional, semantic, behavioral) and optimization (correction) of their sexual behavior and lifestyle (in the form of their own health care programs and their next practical implementation).

However, it should be noted that the importance of sexual education for the youth is not unanimously recognized in all European countries, and in the world countries. Significant role is played here by political and religious factors. Sexual education is compulsory in Austria, Belgium, Greece, Denmark, Estonia, Iceland, Ireland, Latvia, Luxembourg, the Netherlands, Germany, Norway, Portugal, Romania, Slovakia, Finland, France, Czech Republic, Sweden. In most of these countries, the program receives quite significant state support. Optional sexual education is offered in Bulgaria, Great Britain, Spain, Italy, Cyprus, Lithuania and Poland.

By studying the state of sexual education in European countries, we have come to the conclusion that the age from which it begins also significantly varies. Yes, in Portugal it is taught from the age of 5, in Belgium, France, Sweden -6, in the Czech Republic, Great Britain, Finland - 7, and in Spain, 
Lithuania and Cyprus - from 14. Some parents have negative attitude towards sexual education of preschool children, not wanting to understand that it is not bad when the child will at an early age know where children come from, and parents will not have to puzzle themselves and look for necessary words to explain to the child such a difficult topic. It is better to let this to be done by competent people-educators professionally.

It deserves emulation the early beginning of sexual education in many countries of Europe. Elementary school is best suited to teach children the basic knowledge that will later be expanded. Experts say it is too late to start sex education, when the children are already in puberty. In younger forms, children are less shy of sexual problems, and because of that it is easier to speak about these topics. And they formulate questions easier and freer, without hesitation and shyness to classmates.

Sexual education should begin with forming a fundamentally positive attitude toward sexuality and sexual health, rather than relying on deterrence, risk-intimidating. According to French educators, sexual education that focuses only on problems and risks does not synchronize with the interests, needs, and experiences of children and adolescents and therefore will not have the desired impact on their lives and behavior. That is, to replace the negative, should come a more positive approach, which is not only more effective, but also more realistic.

A key problem in developing the content of sexual socialization is the ratio of studying the issues of sexuality and the idea of the abstention from early sexual intercourse. Among the different approaches to sexual education (abstinence, procontraceptive, comprehensive, radical) the most effective, in our opinion, is a comprehensive (combination of the abstinence with a procontraceptive approach) sexual education, and the least rational is abstinence and radical sexual education.

The French experience of the organization in the colleges and high academies of three sessions of sexual education deserves the attention. They are focusing on not only the biological knowledge, but also on the psychological, emotional, social, cultural and ethical dimensions of sexuality, bind and complement the various lessons taught in the classroom, integrating all knowledge into each head. Sessions are held in the form of debates that broaden the information on prevention (AIDS, STD, contraception) to more existential issues: conversations about themselves, their bodies, relationships with others, feelings of love, relationships between boys and girls, sexism, homophobia.

An important role in sexual education is played by media and the Internet. Their attitude to this problem can be varied depending on the country. In some countries, predominantly in Scandinavia, the media is a source of support and information on sex. In Denmark, national radio and 
broadcaster companies provide free airtime for sexual education programs. In other countries, such as the UK, sex issues are served with a large shade of sensationalism, having a negative impact on the youth sexual education. On Norwegian television were released mini-series about puberty "Pubertet". In short, five-minute educational spots announcer in the simple language tells and shows everything related to sexual maturation. Series are called: "penis", "breasts", "vagina and menstruation" and so on. It is hardly possible to present such on Ukrainian TV.

\section{The history of the sexual socialization formation in Ukraine}

The ideas of sexual socialization in the domestic pedagogical discourse arise in the late 19-th to the early 20 -th century. This was facilitated by feminist movements of the second half of the 19-th century, and the emergence of the first women's magazines, and the emergence of schools and classes of joint education for children of different sexes, and increased attention of domestic scientists to sexual problems, etc. There were several key problems of sexual socialization, namely: to determine by whom, when and how the sexual socialization of the younger generation should be carried out

The first range of questions was related to the justification of major sexual socialization agents: family or school, parents or teachers; the second - to the definition of age, from which sexual education of children should begin. The third range of questions was connected with the developing of forms and content of sexual socialization of children (principles, approaches, methods and techniques).

In general, it can be noted that in the 19-th and early 20-th centuries in Ukraine there were the same processes in the sexual issue, as in Europe, and they were discussed in the same intellectual direction. Domestic pedagogues actively studied foreign experience of resolving sexual issues. There were issued the works of G. Bedley, I. Bloh, O. Weyinger, A. Moill, A. Forel, S. Freud, S. Shtil and others, who influenced the domestic public opinion of the time. The importance of sex education was emphasized as precautionary measure created to enclose the youths from morally vulgar acts, to develop in boys and girls the feeling of shame and neatness, to strengthen their will.

In most publications on sexual issues late 19-th -early 20-th century. (N. Zharintseva, M. Lishnevska, V. Polovtseva, G. Rolleder, etc.) sexual socialization was considered rather purely medical, hygienic and not pedagogical problem. The leading role was given to the sexual education. Thus, educator K. Zhytomyrskyi said: "If we want our children to be pure and free from false (dirty) representations relating to love, marriage, 
procreation, motherhood, feeding, puberty, it is necessary to teach children the truth, not to leave them alone with themselves" ${ }^{\prime \prime}$

However, there were the works (for example, by O. Vodovozova), in which it was stated that by only informing the problems of sexual socialization cannot be solved, because knowledge of the basics of sex hygiene do not provide social sexual behavior. It must be supplemented by the proper organization of sexual education, aimed at strengthening the will, development of good habits and a sense of duty.

Significant changes in the views on the issue of consideration of sexual differentiation in the educational process took place in 1920's. As in the previous period, this problem continues to remain in the focus of the pedagogues in connection to the problem of joint education. The problem of accounting for sexual differentiation is solved in the socio-political context and is reflected in the state resolutions of that period relating to the goals, principles and the organization of the Soviet school. Now the teachers began to pay more attention to the study of differences between the sexes, and in the interpretation of the content of sexual education, there was a gradual shift from the accent of biological, sexual component to the social, moral and ethical.

It should be noted that in 1920's the early 1930's the problems of sexual pedagogics were developed mainly by pedagogues. In the writings of Ye. Arkin, M. Serebrovska, V. Bekhterev, B. Raykova, M. Basova, A. Zalkind, K. Veselovska, P. Blonsky and many others the age dynamics of child sexuality and variation were studied, the deviations in sexual behavior of children were explored, an idea of sexual education, as a set of organized pedagogical influences on a developing person with the aim to develope conscious sexual behavior was formulated, the need for close communication of sexual education with other spheres of training and educational work was pointed out, the methods of sexual education in the course of teaching of various school subjects were developed.

The generalization of the ideas and provisions of domestic sexual pedagogy of the pre-war period was the in the work of P. Blonsky "Sketches of Children's Sexuality" (1935), in which the verdict of Soviet pedagogy was rendered, which ignored the question of sexual socialization of the school youth. The author especially emphasized that sexual pedagogy should not so much inform but to educate, and since human sexual life has rich social meaning, then the sex life should be above all socially moral.

After the publication in 1936 of the resolution of the CC CPSU (b) "About pedological distortions in the system of People's Commissar" the researches, in particular on issues of sexual socialization, the puberty of

\footnotetext{
${ }^{9}$ Житомирский К. Эмансипация педагогіки. Москва, Янус К., 2002.
} 
children in the USSR were prohibited, the polls on issues of sexual policy weren't carried out, the sexual education was stopped. The problems of sexual education were removed from school, and the pedologists who at least actualized the sexual problems were subjected to prosecution.

The ideological defeat and the party condemnation of pedology not only closed the issue of sexual socialization of children and teenagers to discuss them on the pages of pedagogical periodicals, not only removed the gender from the Soviet school, but also gave a start to the new Soviet pedagogy as a science of the "communist education of the rising generation". Gradually, the country had a situation, which A. Petrovsky called "sanctimonious desexualization", "non-sexual education".

After the defeat of pedology and during the postwar years, the Soviet school in Ukraine ignored the problem of sexual socialization of students. Most teachers had seen their task of "banning", "to eradicate" love at school, or simply to not notice it. Even the possibilities of basic subjects were not used enough. Revealing in this regard is that in biology classes, when they reached the topic of "reproduction", teachers usually offered schoolchildren to study this material on their own.

With the introduction to the national school of the course "Ethics and Psychology of Family Life" (1983), there appeared hope for preparing young people for the right intersexual relations. But the ill-conceived content of the subject, the low level of its teaching, unprofessionalism in the work of teachers, their complexes and phylactery, rejection of the subject by parents and teachers - all these have resulted in the problems of sexual socialization, development in children and adolescents a healthy attitude towards gender, sexuality, and relationships of genders, family planning, and the prevention of pregnancy which were left out of this course. In general, Ukrainian pedagogical science of the Soviet period didn't cope with the tasks of sexual socialization. Pedagogics of sexuality failed.

Although the general trend and the main tendencies in the development of domestic sexual culture in the second half of the 20-th century were the same as in the West, there are significant differences between them. They are primarily in chronological framework of development and a measure of public awareness of changes occurring. Firstly, these changes occurred with significant lag in time (about 10-15 years). Secondly, there is a significant difference in the level of reflection of the changes that occur in the national and Western European sexual revolution, a different correlation of behavioral and ideological, discursive components. In democratic countries in Europe the shifts in sexual behavior preceded shifts in social attitudes, which were expressed and discussed publicly, so that "the public ideology of sexuality has changed earlier than the sexual practice". The situation is similar in Ukraine at the domestic level. However, censorship bans 
(especially before) and the lack of professional discourse (today) hinder the awareness of these shifts, which because of this seem to be unexpected and catastrophic, and sometimes actually become so. Thirdly, in Ukraine much stronger than in the West, a double standard of sexual attitude is maintained. Moreover, the generation gap in the issues of sexual culture is not only greater than in the West, but also than it was there during the sexual revolution of 1960-1970's.

There is another problem of inconsistency, which arises from the cultural differences in domestic adolescents in relations with Western partners. This problem is a different understanding of the voluntariness of sexual relations, the responsibility for sexual relations, and the constancy of these relationships. The basis of sexual relations in the West are usually two factors: the voluntarity of relationships and the activity of both partners. No one should serve the role of a "victim" and no one should dominate a relationship. Both partners play an active role and both partners should not doubt the voluntariness of the partner.

One more point is the controversial correlation of the principles of sexual liberalism and gender equality. In the Scandinavian countries the peak of sexual tolerance was achieved in 1970's, now some of its manifestations, such as prostitution and pornography, are criticized in terms of gender equality. In Ukraine, liberalization began later, got forms of commercial sex and is often combined with downright sexism and traditionalism, as soon as it came to the right of women in sexual self-determination. Changes in sexual behavior of young people accompanied by significant social disabilities took the Ukrainian society and state by surprise.

The sexual revolution in Ukraine became rather informational than factually. In contrast to the western countries, it took place in the conditions of medical and sexual ignorance of not only teenagers but also adults, undeveloped family planning services, the absence of teenage gynecological service. It has created a rosy myth about sex, modeled the unreal ideal of total sexual satisfaction, preaching the idea of some magical sexual paradise. And, as always in such cases, it arose mass of unfulfilled expectations. We can confidently say that it is sexual ignorance - the main difference between domestic teenagers and their western peers. Young people quickly adopted a foreign tendency to early sexual relations, but did not think about the consequences. The ignorants, who in one phrase in the native language makes five mistakes and can not call the population of the country where they live, do not know Ukrainian writers and the year of beginning of the Second World War, but are drawn to sexual actions.

In Ukraine, attitudes towards sexual socialization were and remain controversial. Sex education as an aspect of moral education was recognized and encouraged by the scientists, but the question of sexual education was 
filled with contradictions. So, V. Sukhomlynsky wrote: "We, the eldest generation, must learn to speak with children and the youth about the great and beautiful love, marriage, procreation..., ignorance in this area turns into the tears and grief of children ", 10 . And he advises to answer questions about the mystery of birth with the help of tales about the stork, considering such answer moral, that develops innocence and protects from "rudeness and primitivism" of the true answer.

Almost noone is engaged in organized sexual socialization of Ukrainian teenagers, because it seems to inevitably entail mental and sexual deviations. Sexual illiteracy provokes irresponsible and dangerous sexual behavior. As some of the famous said, sexual behavior of teenagers corresponds to the 21 -st century, but their sexual consciousness and knowledge remain at the level of the mid-twentieth. In this case, speculation often takes place without appropriate links to the opinion of psychiatrists and psychologists, who, as a matter of time, has long known that getting into the sexual sphere inhibits the cognitive activity of the child.

Some reduce sexual education to the hygienic knowledge. Others believe that the youth should receive the sexual education through self-education search for information and experimentation. Objecting to the adults' chats with the children, A. Makarenko laid responsibility on the children themselves: "Do not be afraid of what the child knows about the mystery of procreation from their comrades and friends..."

As a consequence of the foregoing, the main trends in the development of mass sexual culture in Ukraine today are: vulgarization, narrowing down complex love-erotic feelings and experiences to the primitive and standard sexual techniques; commercialization, the overprofits of the sex industry, which has nothing to do with ethics, either with aesthetics or with pedagogy; westernization (targeting at the western pornographic market); hedonization, when sexual pleasure is recognized as a positive social and cultural value and is included not only in household but also in high culture; The temporality of a sexual partnership that is a derivative from high social mobility, which creates a situation of unsafeness and social uncertainty, etc.

Traditionally, sex education in European countries focuses on potential sexual risks, such as unplanned pregnancies and STD's, that is, it increases the emphasis on the prevention of problems relating to the intimate sphere and personal sexuality. Experts are convinced that this approach is negative, as it focuses only on the problem, and it does not always correspond to the curiosity, interests, needs and experience of the young people and therefore does not have proper influence on their behavior.

${ }^{10}$ Сухомлинський В.О. Батьківська педагогіка. Київ : Рад.школа, 1978. 63 с.

${ }^{11}$ Макаренко А.С. Твори в семи томах. Т. 4. Київ : Рад.школа, 1964 
Today in Ukraine it is recognized that sexual socialization, which includes issues of education and upbringing is socio-pedagogical problem, that is, pedagogy as a science of pedagogical processes is designed not only to identify the good conditions to sexual socialization, but also takes into account the biological and social aspects of the child's life of both sexes.

Problematic areas of modern sexual pedagogy are:

1. Conceptual apparatus. The definition of gender, sexuality, sex, and features of sexual education, and the formation of sexual culture, etc., because there is a constant substitution of these notions in the scientific literature.

2. Age parameter. This issue is substantially related to the solution of the first problem. Of course, when it comes to sexual education, to appeal to preschoolers and younger pupils is more than problematic. But if we talk either about sex education, or about the system of psychological and pedagogical accompaniment, which affect the psychology of the personality in general, the problematic becomes some delay in appeal only to teenagers.

3. A leading social institution. Who: Family, school, doctors, psychologists should play a leading role in sexual socialization.

4. Semantic parameter. What should be the program of sexual education and forming of sexual culture? What and when should a child know in a particular age?

5. The methodical parameter. Whether it should be a separate subject, or introducing conceptual elements of sexual socialization to the school curriculum as a whole; should it be optional or a system of extracurricular lectures and consultations of specialists of different spheres, etc.

\section{CONCLUSIONS}

Completing a comparative analysis of the foreign experience of sexual socialization in Contemporary History, it is necessary to report - why should we study it in Ukraine? Because the processes we have encountered recently have a global nature, but in western countries they are much earlier and therefore better studied, that allows us to speak not only about the reasons of the relevant phenomena, but also about possible long-term consequences.

The purpose of this study was to cover the wide range of educational programs of preparation the students to family life in Europe. Despite the unique cultural differences that can be found in different countries, some communities have similar cultural heritage and practices through common languages, traditions and symbols. While some educators are trying to plan and implement successful sexual socialization programs, which are culturally neutral and oriented more on similarities than diversity, the goal of this study is also to recognise various cultural differences among different populations. 
At the same time, a lot of Ukrainians believe that complex and controversial tendencies of social development are caused by "fall of morality" or influence of "perniciousWest". Some responsible persons actively convince everyone that the European experience of sexual socialization of children is not suitable for Ukrainian conditions and it brings only harm. But this is not so! Many countries made long held large-scale research of the results of the implementation of various methods of sexual socialization, including schools. A huge experience was accumulated in its study, and in a number of cases, separate programs did not give a positive result. Not to use these conclusions would be, at least, irrational, but to say more accurately, it is criminally. The combination of insufficient awareness, scientific ignorance and political engagement creates preconditions for the formation of wrong social policy and education strategy, which entails serious consequences.

However, comparing data from individual countries should be cautious, it is anacceptable to duplicate someone else's experience, mechanical transfer to the national soil.

Comparative analysis of sexual socialization for schoolchildren in the European Union and Ukraine eloquently showed the need to develop a new direction of pedagogical research - sexual pedagogy, the subject of which should be the formation of sexual experience and human sexual culture and determination on this basis the process of its socialization as a specially organized pedagogical process, patterns and principles of organizing sexual socialization of the rising generation.

\section{SUMMARY}

I the article there is a comparative analysis of the problem of sexual socialization of the youth in the leading European countries and Ukraine in the Modern history of Europe. Foremost the main stages of sexual socialization in the European educational space in the 20-th at the beginning of the 21-st century are pointed out. The role of sexual revolutions in transforming attitudes towards sexual youth socialization is marked. The differences in approaches to it in the countries that belonged to antagonistic camps are shown. The reasons for the shift of sexual values of modern youth in the late 20-th - early 21-st centuries are analyzed, and the social consequences of this are disclosed. Comparative analysis was subjected to various (liberal, conservative) programs of sexual socialization in different countries of Europe and Ukraine, their positive and negative sides were marked. On the background of European processes the history of formation of sexual socialization in Ukraine is shown, the peculiarities of sexual influences on the Ukrainian youth are revealed. The main tendencies of the mass sexual culture development in Ukraine at the beginning of the 
21-st century are highlighted and the tasks of pedagogy and school on its formation were formed. The ways of the implementation of foreign experience in the domestic practice of premarital training and sexual education are analyzed.

\section{REFERENCES}

1. Даценко I. Підготовка школярів до сімейного життя в Республіці Польща. Статева соиіалізачія та підготовка учнівської молоді до сімейного життя у педагогіщі та шкільній практиці зарубіжних країн. Монографія. Тернопіль: ТзОВ “Видавництво Астон”, 2009. С. 152-171.

2. Дебесс М. Подросток. 20-е изд. Санкт Петербург : Питер, 2004. $127 \mathrm{c}$.

3. Житомирский К. Эмансипация педагогики, Москва : Янус К., 2002.

4. Каган B.E. Воспитателю о сексологии. Москва : Педагогика. 1991. $256 \mathrm{c}$.

5. Кравець В.П. Історія гендерної педагогіки. Навчальний посібник. Тернопіль : Джура, 2005. 440 с.

6. Кравець В.П. Сексуальна педагогіка. Навчальний посібник. Тернопіль:ТНПУ ім. Гнатюка, 2016. 320 с.

7. Левчик Н.С. Підготовка учнівської молоді до виконання батьківських обов'язків у США та Великій Британії : дис. канд. пед. наук : 13.00.07 / Наталія Стефанівна Левчик. Тернопіль, 2010. 180 с.

8. Макаренко А.С. Твори в семи томах. Т.4. Київ : Рад. школа, 1964.

9. Потапова T. Життя без дітей: чайлдфрі по-українськи. URL: https://life.pravda.com.ua/travel/2009/11/12/33004/.

10. Про педологічні перекручення в системі Наркомосів: Постанова ЦК ВКП(б) від 4.07.1936 року. Закони СРСР 1917-1992 рр. Київ, 1993

11. Сухомлинський В.О. Батьківська педагогіка. Київ : Рад.школа, $1978.63 \mathrm{c}$.

12. Таежная А. Эволюция гендера. Как менялись роли мужчины и женщины в обществе URL: https://www.wonderzine.com/wonderzine/life/ life/201607-gender-role-playing.

13. Camilleri S. Guidelines on sexuality and relationships education in maltese schools. Ministry for education and employment, Directorate for Quality and Standards in Education, 2013 (december). 16 s.

14. Haeberle E. Children's sexual thinking. A comparative study of children aged 5 to 15 years in Australia, North America, Britain and Sweden. London : Routledge \& Kegan Paul, 2013. 42 s.

15. Molina D., Torrivilla I., Sánchez. Significado de la educación sexual en un contexto de diversidad de España / Denyz Luz Molina, Irsia Rosa 
Torrivilla, Yolimar Gregoria Sánchez. Electronic Journal of Research in Educational Psychology, 2011. № 23 (9). pp. 415-444.

16. Rogow D., Haberland N. It's all one curriculum volume 2: activities for a unified approach to sexuality, gender, hiv, and human rights. Education, 2009. 196 p.

17. Sohn A.M. Du premier baiser f la cove: La sexualite des Francaisau quotidian (1850-1950). P. : Aubier, 1996. 866 p.

18. Stern E. Die Erziehung und die sexuelle Frage. Berlin, 1927. 340 p.

\section{Information about the authors:}

Kravets V.P.,

Doctor of Pedagogical Sciences,

Professor of Pedagogical Department

Ternopil Volodymyr Hnatiuk National Pedagogical University

2, Maxyma Kryvonosa Str., Ternopil, Ukraine

Kravets S. V.,

Ph.D in Philosophy Sciences,

Associate Professor of the Theory and Practice of Translation Department

Ternopil Volodymyr Hnatiuk National Pedagogical University 2, Maxyma Kryvonosa Str., Ternopil, Ukraine 